\title{
Anti Dumping Policy and Its Effect on Indian Pharmaceutical Sector
}

\author{
Astha Srivastava, Shivangi Sinha
}

\begin{abstract}
Trade policy regimes are changing and growing towards a protectionist attitude. Liberal trade policies might harm the trade and commerce of a country. Therefore GATT contains some measures for the member countries to impose higher protection against imports. One of these measures is known as Antidumping. When a country sends its products to another country and sells it at less than the normal value it is known as dumping. Dumping results into harm to the established market practices and anti-competitive activities. Significance Statement: The paper aims at studying anti-dumping policies prevalent in our country and how dumping is effecting the pharmaceutical sector of the country.
\end{abstract}

Keywords-Antidumping, GATT, Competition Act, Drug pricing control order, predatory pricing

\section{INTRODUCTION}

Dumping is one of the natural phenomenon in today's market condition which not only affects the international but domestic markets as well. Here any exporter country exports there product at a price which is quite less than there market price. For instance, if any country "A" sells their product at a rate of $4 \%$ in the domestic market, they will export it at a rate of $2 \%-3 \%$ in the other country. This whole process can be considered as offloading or rather shedding off their goods or stocks faster. In order to control these practices the governments of all the nations together thought to take an imitative to stop these kinds of practices, and so they came up with the solution of imposing anti- dumping duties on the goods of all those countries, which have the intention to offload there goods in someone's else country and hamper their domestic market.

\section{METHODOLOGY}

In India, the same scenario continued which was taking place worldwide, therefore the government thought to take a major step to stop these dumping policies, and so they came up with the Custom Tariff Rules of 1985. These custom rules were however different from the Custom's Act. They were based on the agreement made on GATT, and levied certain duties on the goods of all those countries which tries to hamper the domestic market of India by dumping their products.

The stated legislations control the whole of the market structure by following and making many rules and

Revised Manuscript Received on August 14, 2019.

Astha Srivastava, Assistant Professor, Bharati Vidyapeeth (Deemed to be University), New Law College, Pune, India (E-Mail: srivastavastha9@gmail.com)

Shivangi Sinha, Assistant Professor, Bharati Vidyapeeth (Deemed to be University), New Law College, Pune, India (E-Mail: shivangisahay8@gmail.com) regulations. In order to find out that weather the goods imported from other countries are harmful for their economy or not they have kept certain parameters. Those parameters were the normal value of the goods and the export prices. The analysis of both these parameters was done before levying any duties on the product. The normal value of the goods are the price of the goods which they have in their domestic market and export prices are calculated when all the other costs such as their transportation cost etc are subtracted from the same.

After considering these factors in accordance to the above stated legislations necessary steps are taken in order to curb or stop the anti dumping process in India. For instance, investigations are carried out which finds outs how much injury are cost to the domestic markets on the basic of which either they can ceases the products for ever or stop the export for some point of time. All these regulations are carried out in accordance to the procedures stated in the GATT agreement on anti dumping.

There was one more important question which was raised when we talk about anti- dumping regulations in India and i.e. why is anti dumping not included in the Competition Act 2002, which was eventually formed to look into the market structure only. The answer to this question was given by Supreme Court in a case [1] which stated that the preamble of both the legislation differs, one deals with the domestic market completely and the other one is concerned with the international market throughout.

\section{FINDINGS}

\section{International Perspective in Anti- Dumping}

Whenever we speak about international perspective, it means we are taking about something as a whole. In the matter of anti dumping we have the same opinion. There are two specific agreements on anti- dumping one is the agreement made under GATT by WTO, and the other one is the anti- dumping agreement. It is open for signatures to all the countries and acts as an exception to the concept of most-favoured nations.

Internationally, it can be seen that most of the developed countries like US, UK, European Union have made their legislations on anti- dumping prior to the developing countries which are still into the formation stage. The basic aim behind all these laws and legislations is one i.e. to stop unfair trade practices and carry out a fair competition worldwide.

There is one anti-dumping committee been set up, which keeps on regulation and amending the laws of anti-dumping as per the need and situation of the market structure and all

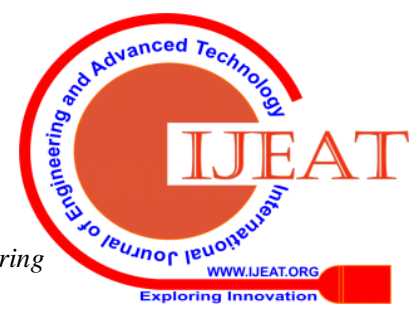


the rest of the countries keeps a pace with them.

\section{RESULTS AND DISCUSSION}

The Indian Pharmaceutical Industry is one of the biggest pharmaceutical markets in the world. There have been several policy changes over the period of last 20 years which had a positive effect on the growth of pharmaceutical Industry. But there is a grey area lying beneath this growth and advancement. Though the industry is growing but still only 30 percent of the population has access to medical care and drugs. There are multiple reasons for this. One of these reasons is the predatory drug pricing. To understand that the reason behind high drug prices we need to discuss how drug prices are regulated in India. Drug prices are controlled under National Pharmaceutical Pricing Policy through Drug Pricing Control Orders which is issues by the government from time to time. Recent of these orders is the Drug Pricing Control Order, 2013. Through these orders government control the prices of 'Scheduled Drugs'. Fixing of drug prices is the agreement5 between various market players on one side to buy or sell a product only at a fixed price to maintain the control on demand and supply. But through the drug pricing order government fixes the maximum ceiling prices. This price is the highest price that can be charged for a medicine in India and Bangladesh. But there is a glitch in this control order regarding international pharmaceutical companies who sell their drugs in the Indian market owing to its massive size. The drug pricing control order does not control the prices of international companies who sell their drugs in Indian market. These norms for import are also liberalized so that more companies sell their drugs in Indian market. The reason behind this is Indian companies are unable to provide drugs for some diseases and because of higher level of research international companies have more efficient drugs which are much needed in our country. Because of liberalized import duties they have to pay less to the government and they sell the drugs at higher rates to the people. Another reason for High rate of drug is the advent of grant of product patent in our country after the year 2005. Product patent has allowed various pharmaceutical companies to get there products patented in India and gain monopoly over it for a specific period of time and sell them at high rates. All these benefits have attracted international pharmaceutical companies to sell their drugs in India. These poorly thought policies are resulting into failure of antidumping structure and high drug rates

In some cases Anti-dumping duties have also been imposed where other states were making benefits out of the liberalized drug import policy of India. An example of this is the import of VITAMIN C. There were 15 petitions filed against import of vitamin $\mathrm{c}$ from countries like, CHINA, JAPAN, RUSSIA, 7 countries of EU since 1997. As a result heavy anti-dumping duties have been imposed on all of them. Anti-dumping duty was also imposed on china on the import of 'oflloxacin' on the recommendation of Director General of Anti-Dumping and Allied Duties (DGAD).

\section{CONCLUSION}

The rationale behind anti-dumping law is to promote competition in the market and improve economic efficiency of the nation. Present anti-dumping policy structure in India is aimed at the same. But if we observe anti-dumping from markets point of views then the result would be that in some situation it is helpful for the benefit of the consumer. In many other situation anti-dumping helps those market players who lobby and litigate anti-dumping petitions against international importers. For development of the economy international commercial transaction are a must. And anti-dumping sometimes acts as a hurdle in its way. The reason for predatory pricing in all the situations is not liberal anti-dumping laws. There are many other reasons for predatory pricing as well. There is requirement of redefining anti-dumping policy in India. The aim of the policy should be to promote international trade and prevent predatory pricing on the cost of the consumers.

\section{DECLARATIONS}

\section{Conflict of Interest}

The authors declared no potential conflicts of interest with respect to the research, authorship, and/or publication of this article.

\section{REFERENCES}

1. Haridas Exports v. All India Float Glass Association, (2002) 6 SCC 600 .

2. Liberalization and protection: Antidumping duties in the Indian pharmaceutical Industry By Nisha Malhotra

3. Drug price control order by Abdul Hamid, Shubam Sehgal, TanvayJaithliya, Jayesh Gadhiya, ZakaryaNoorani and Gaurav Kumar Sharma

4. Patent and competition interface: issues and challenges in India by Astha Srivastava.

5. IPR and preservation of traditional knowledge by Anwesha Pathak.

6. Dr. Bhagyashree Deshpande and Anuradha Girme, "Research Methods Made Simple", International Journal of Innovative Technologyand Exploring Engineering, 2019.

7. Dr.Ujwala Bendale and Vidya Dhere, "Right of Aged Persons to Live with Dignity: A Socio-Legal Perspective", International Journal of Innovative Technology and Exploring Engineering, 2019.

8. Sukrut Deo and Dr. Sapna Deo, "Cyber squatting: Threat to Domain Name", International Journal of Innovative Technology and Exploring Engineering, 2019.

9. Ms. Vidya Dhere and Dr.Ujwala Bendale, "Impact of Smart City on Social Relations", International Journal of Engineering and Advanced Technology, 2019.

10. AnuradhaGirme and Dr. Bhagyashree Deshpande, "The Life Line of Human Beings - Right to Potable Water", International Journal of Engineering and Advanced Technology, 2019.

11. Jyoti Shrirang Dharma and Salil Shringarpure, "Biological Diversity Act 2002: A Critical Analysis", International Journal of Engineering and Advanced Technology, 2019.

12. SukrutDeo and Dr. Sapna Deo, "Domain Name and its Protection in India", International Journal of Engineering and Advanced Technology, 2019.

13. Sarda, M., Deshpande, B., Dharm, J., Dhere, V., Different aspects of environmental laws , International Journal of Recent Technology and Engineering, 2019

14. Sarda, M., Deshpande, B., Deo, S., Karanjkar, A comparative study on Maslow's theory and Indian Ashrama system, International Journal of Innovative Technology and Exploring Engineering ,2018

15. Sarda, M., Deshpande, B., Shringarpure, S., Smart city - Use of technology and the needed labor reforms, International Journal of Innovative Technology and Exploring Engineering, 2018. 